\title{
INDUSTRIALS AS INVESTMENTS FOR SMALL CAPITAL.
}

By JAMEs B. DrL,, Essq., of New York City.

I.

The industrial movement must stand or fall by the proposition whether industrials are or are not to become an investment for the small capitalist.

I have read articles in public print by gentlemen of learning, sometimes by men of high political reputation, stating how industrials were promoted, organized and financed, but some of these gentlemen seemed to deal in matters other than those with which they had large practical experience. I have listened to presidents and professors of institutions of learning upon the promotion, fnanciering and the launching of industrial combinations. I have read much and heard much upon this subject, but in all frankness I say to you that I have yet to hear from one who has actually promoted, organized and financed a public industrial combination a public statement in detail as to how such organizations are really promoted, organized and financed.

I may add, parenthetically, if you please, that under the topic assigned me to-day I feel it would not be relevant for me to be the first to break this silence.

We are told that combinations are brought about by natural causes, that it is a natural evolution, and while it is quite true that antagonistic competition and business surroundings have tended to bring together the great industrial combinations, yet it has not always been for the good of the public at large that these large combinations have been created. It has sometimes been primarily for the good of the pocket of the promoter and the financier. The result of the promoter and the financier in combinations often appears in watered stocks, and overcapitalization. 
The industrial of to-day is not always looked upon as the most conservative investment or as the security most desirable as bankable collateral, because many contain the promoter's reward concealed in the stock issue, resulting often in excessive capitalization. Recognizing this fact the true industrial does not always pay dividends upon its common stock, but quite frequently devotes its surplus earnings to making good the capital issued for good-will or other intangible property, driving out the water, if water there be, and creating a financial reserve ordinarily, but sometimes inaccurately, designated as surplus.

The true industrial withdraws its stock from speculations in the market, aiming to convert its stocks into securities valuable as an investment. The volume of trading in its stocks is sought to be decreased, to make its holdings of stock permanent rather than fluctuating.

Industry always, speculation never, affords a nation security, prosperity and ultimate success. The pursuit of the gambler and the occupation of the merchant are of widely different character. The true industrial differs as widely from the too common speculative specialty that goes under the name of the industrial as the merchant differs from the gambler. Such speculation is the opponent of industry, and speculation and industry cannot go hand in hand in any one organization.

If it be possible for any one man or body of men controlling as officers any industrial corporation, to close any factory or number of factories, to throw out of employment, either temporarily or permanently, large numbers of men; if it be possible that this may be done for the mere purpose of stock speculation, then it certainly follows that there is just cause for fearing grave disaffection. That combination whose energies through its board of directors and officers is mainly given to the Wall street end of the proposition is not an industrial in the true sense of the word. That corporation whose board of directors or officers devotes more time and 
more attention to the ups and downs of the market price of its stock than it does to the distribution of dividends among the stockholders, to the increase in effectiveness of production, to the cheapening and bettering of the article produced, is the opponent of every honest combination of capital.

Without seeking to excuse the improper promotion and the unwise financiering, we must recoguize the law of supply and demand. People are largely furnished with what they call for. The promoter and the financier, in bringing these combinations together, have had a keen eye to the public demands and in the future will have the same keen eye to what the public will take. If the public demands an investment they will be inclined to furnish an investment; if the public asks for a speculation, or gambling specialty, the promoter will flood the country with these until financial ruin stares many in the face.

As long as the American public are willing to gamble with the industrial interests of the country, just so long will the promoter force the water into the great arteries of trade, subverting the great industries of the nation into the mere tools for the gambler and the speculator, eventually resulting in the great injury to a nation of industries. This by no means excuses vicious promotion, or improper financiering, but speculation tends to encourage both evils.

There are certain invariable marks of promotion, speculation and schemes which will point the true character of the organizations beyond the possibility of a mistake. When one finds in the charter the language found in so many: "The stockholders shall have no right to examine the acounts, vouchers, books, papers of the company, except so far as they are granted by statute," the conclusion is inevitable that information will not be freely given to the stockholders.

A provision that the directors shall at the first election be divided into classes, a majority elected for a maximum term of years, suggests that those in control are not willing to 
leave to the stockholders the question of whether they prove to be the proper managers of the business, are not willing to delegate to the stockholders in their annual meetings the power to displace the board, if the management is either mistaken, erroneous or even fraudulent. 'Thereby the promoters and financiers perpetuate themselves in office for a term of years, leaving the stockholders without recourse, by an examination of the books, to discover whether or not the business is conducted properly, taking from the stockholders the right to go to the stockholders at large and to open the question of the propriety or impropriety of the board of management.

There are industrials true and fictitious, there are wolves in sheep's clothing parading as industrials. The classes are clearly distinguishable if a proper examination is made. We have professional men who examine titles to real estate. We have Title Guarantee Companies who issue policies of insurance on titles, but the people seem to have no bureaus of information as to the industrial promotions and gambles that are so freely offered to the public, upon which they can rely with safety. The Exchanges do not seem to have resulted in keeping stocks improperly designated as industrials from the market.

Industrial combinations are producing a new class of financiers, a new order of corporation men. Business character and personal character cannot, in the long run, differentiate widely. Every corporation which attempts to go to the public and to place its securities should be held to the responsibility of selecting men of integrity and standing as its officers and directors. The institution which places stock manipulators and speculators in charge of its affairs should be promptly classified. The company which fails to put men in its board who feel themselves charged with a large and public duty toward its stockholders should fail to find a market for its securities.

If the journals of trade and commerce in our great 
cities would accurately and impartially analyze the charter and by-laws of each corporation whose stock is to go to the public, the public would soon be educated as to the difference between the industrial and the Wall street gamble.

Panics would be confined to the promoters, and not extend to the investors, if the public examine first, invest afterwards. No man would invest $\$ 1,000$ or $\$ 10,000$ in the purchase of real estate, or loan that amount on real estate as security, without an examination of the property, a knowledge of its value, a certainty that it actually exists, and assurances that the title is good.

Use the approximately same care in the investment of $\$ 1, \infty 00$ or $\$ 10,000$ in an industrial security, and the first thing an investor will do, will be to demand an examination of the certificate of incorporation and the by-laws of the company. Although the stock is wholly dependent on the certificate of incorporation (sometimes called the charter) and upon the by-laws, yet the average man as a rule does not ever ask to see the charter or the by-laws. If every investor would insist upon seeing and understanding the charter and by-laws, and as well an accurate financial statement of every company before he would buy the stock, it would produce a revolution in corporate matters.

The law of supply and demand is the strongest law that can be invoked, and if there is a demand for speculative specialties in this country, the so-called industrials will be put together to answer that demand, rather than a demand for honest investment on the part of permanent investors.

It depends upon whether the investor demands information as to what he shall bny, as to whether he selects and exhibits the same care in the purchase of industrials as he would in the purchase of a horse, as to whether he exercises a fraction of the care in the purchase of industrial investments which he does in the purchase of the same amount of a real estate investment. 
II.

The entire country is demanding secure, interest-bearing investments in small denominations. The industrial combinations of to-day should furnish such investments. To-day the capital of corporations of integrity is sought for by investors for the returns which they afford, and the safety which they give.

Too many so-called industrials are not true industrials. If and when the industrials are properly classified, put upon a business footing, fictitious valuations adjusted, then, and not before, will industrials as a class become an investment.

The fact that the stocks of any company are largely the subject of speculation is an argument against its soundness and its integrity.

When a stock becomes an investment, then we are assured of the stability of the enterprise, we are certain that the business is being conducted for the benefit of the stockholders as a whole, rather than for the benefit of the few in power, by means of speculative enterprises. When an industrial combination places its securities upon the level of true investment for small capital then, as to that corporation nine-tenths of all the difficulties and doubts surrounding the present evolution of capital and combination are solved and settled.

The relation of labor to great combinations of capital is largely solved when the laboring man owns and holds as investments the stocks of the corporation. That corporation whose stocks are truly an investment, which takes the place with the laboring man of the savings bank, but at 6 pet cent. instead of 3 per cent. interest, is on a sound basis and is not in conflict with the laboring man because he is a part of the corporation itself.

The question is often raised whether the real estate investment is the best for the laboring man. It has been argued that that laboring man who owns his own home instead of renting one, is so tied down that he is not able to avoid the 
cutting down of his wages or to move elsewhere if higher returns are offered for his labor. The converse of this proposition appears when the laboring man holds the stock as an investment.

\section{III.}

Finally, the question of the investment in industrials is not to be discussed from the standpoint of the promoter, the financier and the banker, but from the point of the ultimate distribution of industrial securities, that is, of the investment by the people at large, the small capitalist.

By the small capitalist, I refer to that class of men who have from $\$ 100$ to $\$ 10, \infty 00$, or more, to invest, and who, according to the argument of those opposed to combinations, are forced to withdraw their capital from mercantile business because of the pressure of competition resulting from combinations or from other results of the organization of capital. It solves the question of the small merchant otherwise perhaps forced out of business by competition.

If we accept the statement as accurate, that the man with $\$ 10,000$ invested in the dry goods business in the city of Philadelphia, may be driven out of business by reason of the greater inducements offered to the public by such business houses as that of Mr. John Wanamaker, then it is equally important to this man whose $\$ 10,000$ has been withdrawn from business that it should be reinvested with more security if with perhaps slightly less income from the capital.

The safety of industrials lies in the investment by the small capitalist rather than the large capitalist because, so long as the control of these large corporations is wholly in the hands of the large capitalist the corporations themselves may be managed for the best interests of the large capitalist rather than for the individual stockholders and the country.

The question then may possibly be, how can the majority stockholder make the most money, and if that is to be made best in the way of speculation, perhaps by buying and selling 
the stock, or by the artificial raising and lowering of prices. The decision may not rest upon what is for the good of the many, but what is for the good of the few in control. As it is for the good of the industrials themselves, so it is for the people at large, that the small capitalist, the many capitalists and the many stockholders, hold the control of the company through its stock rather than to see it in the hands of the few or possibly the one.

I am forced to treat the subject with brevity and without due explanation or enlargement, a difficulty readily understood when the breadth of the topic is comprehended.

I do not desire to be understood as urging in the present state of affairs careless investments in the stock of all the so-called industrials, nor as suggesting that the common stocks of some so-called industrials are to be regarded as proper investments. I desire to be understood as suggesting that the industrials so-called of to-day include many false industrials; that the true industrials should be distinguished from the false, and that the true industrial is benefited by the investment of the small capitalist, and, on the other hand, in the true industrials (not in the speculative specialties) the small capitalist should find, and often will obtain, an investment reasonably safe and, by reason of the earning capacity of the industrial, productive of a larger income. To the man who needs 6 per cent instead of 3 , the true, not the fictitious, industrial should present an opportunity for investment.

The suggestion attributed to Professor Hadley (perhaps erroneously) that the remedy for vicious promotion and improper financiering was the ostracism of the promoter and the financier to some seems to fall short of practicability. The principle is perhaps feasible applied to the stocks rather than to the men who made them, and I am urging that when and if the people discriminate between the good and the bad and ostracize by refusing to invest in the bad, that the occupation of the manufacturer and promoter of the false 
Industrial will cease to be a profitable one. Certainly the proposition must meet with approval that the nearer the corporation is managed to the line of the true industrial, which aims to make its securities honest and productive investments, to that extent the industrial movement will be improved.

It is also safe to assume that when and if the true industrial is evolved out of the present state of affairs that then the true industrial will be upon a better footing, if its stocks are widely scattered and firmly held by small investors throughout the country.

Combinations of capital improperly organized, managed and conducted for a purpose other than that for which they are apparently incorporated, viz., to conduct an industry on industrial lines, are an evil. Honest corporations, honestly organized, managed and conducted with a single eye to conduct a legitimate industrial business, whose capital is widely distributed, whose stocks are an honest investment for capital small and large, of such corporations we may confidently assert they are a lesser evil if we cannot agree that such corporations are a positive good.

In December last, before the American Economic Association at Ithaca, I had occasion to say that

" It seems true that any tendency in any corporation to have two interests in the business equally important and equally engrossing the attention of the officers, the one the business end of the corporation, and the other the speculative or Wall street end, is a tendency which may be, with emphasis, pronounced dangerous; dangerous to the corporation itself, as exposing it to attacks from sources other than those of the business itself ; dangerous to the officers of the corporation, as tending to take their attention from the one and only end and purpose of the corporation, viz., the betterment of the industry in hand; dangerous to the stockholders, as furnishing them a false and unwarranted indication of the progress, or, as the case may be, the failure of the business itself," 
and I may add that recent events have not changed my opinion in this respect.

It is a matter of congratulation that the consideration of industrial combinations has moved up apace from the original standpoint from which it was first discussed. Mere denunciations, the simple calling of names and the use of adjectives and passionate declamation's have been clearly demonstrated as lacking the weight of statements of fact and as failing to enlighten the public upon what is to-day a topic of pre-eminently public interest.

Not only has the manner of discussion been elevated, but the view point has been carried upwards as well. The main question to-day is not whether the washwoman buys her small quantity of kerosene at eight cents instead of six cents a gallon, the wholesale price, but rather whether the public as a whole are benefited by combinations of industrial capital and benefited, not only as consumers, not only as producers, but what is the finality of the question, as widely distributed investors of capital.

The results of public discussion on both sides of the question have been to bring the thinking men of both parties more nearly in accord, and with the result that the corporate standpoint has been elevated.

Criticisms made upon corporations and upon corporate methods have not always been without foundation. Men of integrity and honesty of purpose, among whom AttorneyGeneral Frank S. Monett of Ohio stands prominent, have done much to elevate the standard of corporate morality in attacking corporate evils. Instead of disregarding the stateements of such men, the wise corporation lawyer carefully weighs them and while from a corporation's standpoint one may not always agree in detail with the learned attorneygeneral, nevertheless, the corporation lawyer profits by his suggestion and endeavors to avoid being unduly subject to fair criticism in these respects.

Corporations of integrity are demanding that the public 
investigate as between themselves and others, in order that their class may not be kept down to the level of those corporations which are otherwise situated. They are demanding, from a corporate standpoint, that the people shall become intelligent upon the subject of industrial securities, in order that the good industrial securities may not suffer with the bad. 